\title{
Penyisihan Parameter TSS dan COD Menggunakan Koagulan Nanokitin dan Kitosan pada Pengolahan Air Sungai Cikapundung
}

\author{
Memey Suhaya Putri ${ }^{1 *}$, Etih Hartati ${ }^{2}$, Djaenudin $^{3}$ \\ 1,2 Jurusan Teknik Lingkungan Institut Teknologi Nasional \\ ${ }^{3}$ Loka Penelitian Teknologi Bersih Lembaga Ilmu Pengetahuan Indonesia \\ *Koresponden email: suhayaputrimemey@gmail.com
}

Diterima: 13 Desember 2019

Disetujui: 17 Desember 2019

\begin{abstract}
The use of excessive synthetic coagulants and continuously will have a negative impact because of the increasing amount of mud volume can accumulate in the human body. The quality of Cikapundung River water has decreased every year, so it is necessary to treat Cikapundung River water through a process of coagulation and flocculation using coagulants made from nanocytin, chitosan and commercial chitosan. Measurement of these parameters uses the gravimetric and titrimetri method. The dose of coagulant used in the process of coagulation and flocculation is $10 \mathrm{mg} / \mathrm{L}$, by varying the $\mathrm{pH}$ value of $\mathrm{pH} 5, \mathrm{pH} 7$ and $\mathrm{pH}$ 9 and the flocculation time variations of 15 minutes, 20 minutes and 25 minutes. The measurement results showed with a dose of coagulant $10 \mathrm{mg} / \mathrm{L}$, commercial chitosan $\mathrm{pH} 5$ flocculation times of 25 minutes can reduce the TSS concentration of $12 \mathrm{mg} / \mathrm{L}$ with $99.38 \%$ total suspended allowance. Concentration of Chemical Oxygen Demand $13.12 \mathrm{mg} / \mathrm{L}$ with $98.91 \%$ allowance. The TSS value has fulfilled the quality standard according to Government Regulation Number 82 of 2001 concerning Management of Water Quality and Water Pollution Control in the first class.
\end{abstract}

Keywords: Cikapundung, nanocytin, chitosan, TSS, COD

\begin{abstract}
Abstrak
Penggunaan koagulan sintetik yang berlebihan dan terus menerus akan menimbulkan dampak negatif karena meningkatnya jumlah volume lumpur juga dapat terakumulasi dalam tubuh manusia. Kualitas air sungai Cikapundung mengalami penurunan setiap tahunnya maka perlu dilakukan pengolahan air Sungai Cikapundung melalui proses koagulasi dan flokulasi menggunakan koagulan yang terbuat dari nanokitin, kitosan dan kitosan komersil. Pengukuran parameter tersebut menggunakan metode gravimetri, dan titrimetri. Dosis koagulan yang digunakan pada proses koagulasi dan flokulasi adalah $10 \mathrm{mg} / \mathrm{L}$, dengan memvariasikan nilai $\mathrm{pH}$ yakni $\mathrm{pH} 5, \mathrm{pH} 7$ dan $\mathrm{pH} 9$ dan variasi waktu flokulasi 15 menit, 20 menit dan 25 menit. Hasil pengukuran menunjukkan dengan dosis koagulan $10 \mathrm{mg} / \mathrm{L}$, kitosan komersil pH 5 waktu flokulasi 25 menit dapat menurunkan konsentrasi TSS $12 \mathrm{mg} / \mathrm{L}$ dengan persen penyisihan total suspended solid 99,38\%. Konsentrasi COD sebesar 13,12 mg/L dengan persen penyisihan 98,91\%. Nilai TSS tersebut telah memenuhi nilai baku mutu sesuai Peraturan Pemerintah Nomor 82 Tahun 2001 Tentang Pengelolaan Kualitas Air dan Pengendalian Pencemaran Air pada kelas satu.
\end{abstract}

Kata Kunci: Cikapundung, nanokitin, kitosan, TSS, COD.

\section{Pendahuluan}

Sungai Cikapundung merupakan satu dari 46 sungai dan anak anak sungai yang mengalir dari utara di kawasan pegunungan Tangkuban Perahu ke arah selatan sehingga bertemu dengan Sungai Citarum. Kualitas air Sungai Cikapundung di Bandung menurun secara drastis dalam rentang dua puluh tahun terakhir akibat tercemarnya air sungai oleh pembuangan limbah industri dan juga limbah rumah tangga, sehingga kini warga beralih memakai air dari Perusahaan Daerah Air Minum Kota Bandung.

Ketersediaan sumber air bersih di permukaan sangat terbatas untuk itu diperlukan proses pengolahan air [1]. Koagulasi dan flokulasi merupakan salah satu langkah dalam pengolahan sumber air keruh menjadi air minum dengan cara menghilangkan kekeruhannya. Kekeruhan atau Total Suspended Solid (TSS) dapat dihilangkan dengan menambah koagulan dan flokulan yang menjadi gumpalan yang mempunyai ukuran lebih besar sehingga akan lebih mudah mengendap [2]. Jenis koagulan yang sering digunakan dalam proses koagulasi ialah Tawas, Sodium Aluminat, Ferri Sulfat, Polyalumunium Chlorida (PAC). 
Penggunaan koagulan sintetik yang berlebihan dan terus menerus akan menimbulkan dampak negatif selain karena meningkatnya jumlah volume lumpur juga dapat terakumulasi dalam tubuh manusia [3]. Kitosan adalah senyawa polimer turunan Kitin yang telah dihilangkan gugus asetilnya menyisakan gugus amina bebas. Kitosan merupakan biopolimer yang bersifat polikationik sehingga banyak digunakan diberbagai industri kimia antara lain bahan pelembab, adsorben ion logam, kosmetik, pengawet makanan [4]. Kitosan memiliki kemampuan sebagai koagulan karena memiliki banyak kandungan nitrogen pada gugus amina [5]. Gugus amina dan hidroksil menjadikan kitosan bersifat lebih aktif dan bersifat polikationik, sifat tersebut dimanfaatkan sebagai koagulan dalam pengolahan air gambut yang dapat menyerap logam Fe lebih besar daripada PAC [6].

Penelitian ini untuk melihat kemampuan Nanokitin beserta turunannya yakni Nanokitin, Kitosan dengan nilai derajat deasetilasi $32 \%$, serta kitosan komersil sebagai koagulan pengolahan air Sungai Cikapundung agar menurunkan parameter TSS, Chemical Oxygen Demand (COD), total Nitrogen dan total Fosfat yang belum memenuhi baku mutu Peraturan Pemerintah Nomor 82 Tahun 2001 kelas 1 Tentang Pengelolaan Kualitas Air Dan Pengendalian Pencemaran Air.

\section{Metode Penelitian \\ Metode pengumpulan data}

Penelitian ini dimulai dari proses penumbukkan limbah cangkang rajungan sebanyak $\pm 2 \mathrm{~kg}$, kemudian dilakukan pengayakan melalui saringan 200 mesh yang akan digunakan sebagai bahan pembuatan kitosan sebanyak 2 gram.Variasi jenis koagulan yang digunakan pada penelitian ini yaitu koagulan Nanokitin, Kitosan dengan derajat deasetilasi 32\% dan kitosan komersial. Ketiga koagulan tersebut diperoleh dari beberapa tahapan yakni Nanokitin yang diperoleh melalui proses deproteinasi, demineralisasi, ultrasonikasi sehingga didapatkan kitin berbentuk nano. Selanjutnya dilakukan karakteristik kitin seperti SEM (Scanning Elctron Microscopy) dan FTIR (Fourier Transform Infrared), untuk mengetahui gugus fungsi dari kitin dan serat kitin yang akan dihitung besarnya diameter kitin tersebut [7].

Kemudian Kitosan dengan deasetilasi 32\% diperoleh melalui proses deproteinasi, demineralisasi, deasetilasi dengan waktu pemanasan 2 jam 3 kali pencucian serta dilakukan proses titrasi dimana $\mathrm{NaOH}$ sebagai titrannya, untuk mengetahui nilai derajat deasetilasi Kitosan [8]. Sedangkan Kitosan komersil diperoleh dipasaran dengan nama merek Aldrich.

Setelah diperoleh seluruh bahan diatas, tahapan selanjutnya yaitu pengambilan sampel air Sungai Cikapundung di IPAM Dago Pakar Kota Bandung sebanyak 54 liter pada inlet Sungai Cikapundung sebelum unit pengolahan Barscreen. Sebelum sampel air sungai tersebut dilakukan pengolahan, maka diukur terlebih dahulu parameter awal kualitas air Sungai Cikapundung untuk mengetahui karakteristik fisik dan kimia dari sampel yang digunakan serta untuk perhitungan efisiensi penyisihan parameter pencemar dalam sampel air. Metode pemeriksaan yang digunakan dalam analisis karakteristik sampel air Sungai Cikapundung terdapat pada Tabel 1.

Tabel 1. Karakteristik awal parameter air Sungai Cikapundung

\begin{tabular}{ccc}
\hline Parameter & Metode & Sumber \\
\hline COD & Refluks tertutup secara Titrimeteri & SNI 6989.73:2009 \\
TSS & Gravimetri & SNI 06-6989.3-2004 \\
& & \\
$\mathrm{pH}$ & $\mathrm{pH}$ meter & SNI-06-6989-11-2004 \\
Total fosfat & Spektrofotometri & SNI-06-6989-31-2015 \\
NItrat & Spektrofotometri & SNI-6989-79-2011 \\
\hline \multicolumn{2}{c}{ Sumber : Hasil penelitian (2019) }
\end{tabular}

Setelah parameter awal diukur, diperoleh hasil yang memenuhi baku mutu yaitu $\mathrm{pH}$ sebesar 7,27, Nitrat sebesar $0,018 \mathrm{mg} / \mathrm{L}$ dan total Fosfat sebesar $0,129 \mathrm{mg} / \mathrm{L}$. Sedangkan yang belum memenuhi baku mutu ialah TSS sebesar $1412 \mathrm{mg} / \mathrm{L}$ dan COD sebesar $880 \mathrm{mg} / \mathrm{L}$. Selanjutnya sampel air sungai dibawa ke laboratorium LIPI untuk dilakukan proses koagulasi dan flokulasi menggunakan metode Jartes, dengan dosis koagulan Nanokitin, Kitosan derajat deasetilasi 32\% dan kitosan komersil masing masing sebanyak $10 \mathrm{mg} / \mathrm{L}$ besarnya dosis ini mengacu pada jurnal penelitian [6] tentang pemanfaatan koagulan sebagai agen koagulasi dan flokulasi. 


\section{Variasi Jenis Koagulan, pH dan Waktu Flokulasi}

Selain jenis koagulan yang divariasikan, nilai $\mathrm{pH}$ dan waktu flokulan yang juga divariasikan. Nilai $\mathrm{pH}$ yang divariasikan yaitu $\mathrm{pH} 5, \mathrm{pH} 7$ dan $\mathrm{pH} 9$, nilai tersebut mengacu pada jurnal penelitian [9] tentang Kitosan sebagai koagulan limbah industri tekstil, yang menunjukkan koagulasi optimum. Kecepatan pengadukan cepat (koagulasi) pada sampel air Sungai Cikapundung dengan ketiga jenis koagulan yang telah disebutkan sebelumnya yaitu 120 RPM dengan waktu pengadukan 1 menit yang mengacu pada SNI 19-6449-2000 tentang metode pengujian koagulasi dan flokulasi.

Sedangkan kecepatan pengadukan lambat (flokulasi) sebesar 70 RPM mengacu pada buku [10] tentang proses koagulasi dan flokulasi, dengan waktu flokulasi yang divariasikan pada penelitian ini yaitu 15 menit, 20 menit, dan 25 menit yang mengacu pada penelitian [6] tentang kitosan sebagai koagulan, dan penelitian [11] tentang pemanfaatan koagulan untuk penjernih air. Setelah selesai dilakukan pengolahan secara koagulasi dan flokulasi dengan metode Jartes, 54 sampel air sungai dengan jenis koagulan, waktu flokulasi, dan nilai $\mathrm{pH}$ yang berbeda-beda kemudian dilakukan pengujian TSS dan COD yang dimana kedua parameter tersebut belum memenuhi baku mutu Peraturan Pemerintah No 82 Tahun 2001 Tentang Pengelolaan Kualitas Air dan Pencegahan Pencemaran Air.

\section{Hasil dan Pembahasan \\ Proses Pembuatan Kitin Dan Kitosan}

Berdasarkan metode [12], Kitosan didapat dari proses deasetilasi kitin pada cangkang Rajungan. Ekstraksi kitin dari limbah cangkang Crustacea terdiri dari dua tahap dasar yakni pemisahan protein (deproteinasi) dan pemisahan mineral (demineralisasi). Pada pembuatan kitin dan kitosan dilakukan tahap deproteinasi terlebih dahulu karena protein dijadikan sebagai senyawa yang akan dimanfaatkan lebih lanjut agar protein yang diperoleh mencapai jumlah dan kualitas yang maksimum serta mencegah terjadinya kontaminasi protein pada proses demineralisasi.

Menurut [13], proses deproteinasi kitin merupakan reaksi hidrolisis dalam suasana asam atau basa yang bertujuan untuk memutuskan ikatan antara protein dan kitin. Dengan mencampurkan $\mathrm{NaOH} \mathrm{0,3} \mathrm{M}$ protein yang terlepas membentuk Na-proteinat yang dapat larut dan hilang selama proses pencucian dan penyaringan [14]. Setelah melalui tahap deproteinasi berat limbah rajungan menjadi berkurang yaitu sebesar 152 gr.

Reaksi yang terjadi sebagai berikut :

$$
\text { Protein }+\mathrm{NaOH} \rightarrow \text { Na-proteinat }+\mathrm{H}_{2} \mathrm{O}
$$

Tahap deproteinasi biasanya dilakukan pada suhu $65-100^{\circ} \mathrm{C}$ dan menurut [16] waktu minimal yang dibutuhkan untuk memisahkan lebih dari $90 \%$ protein adalah satu jam. Dua jam tahap deproteinasi dapat menghilangkan seluruh kadar protein [17]. Dalam penelitian ini, tahap deproteinasi dilakukan dengan pengulangan sebanyak tiga kali masing-masing perlakuan selama satu jam pada suhu $80-85^{\circ} \mathrm{C}$.

Tahap kedua yaitu demineralisasi cangkang rajungan $P$. pelagicus menggunakan $\mathrm{HCl} 0,55 \mathrm{M}$ dengan perbandingan massa sampel dengan volume $\mathrm{HCl}$ yakni 1:10 [12]. Tahap ini dilakukan selama dua jam pada suhu ruangan dengan lima kali pengulangan. Berat sampel pun menjadi berkurang seiring berjalannya proses demineralisasi dari 152 gr menjadi 29,5 gr .Menurut [18] dilakukannya pengulangan (successive steps) dinilai jauh lebih efektif dalam melarutkan mineral dibandingkan continuous process.

\section{Pengujian Koagulan}

Dalam penelitian ini dilakukan dua pengujian koagulan yaitu dengan Jartes dan analisa kualitas air. Standar nasional untuk metode pengujian koagulasi flokulasi dengan cara Jartes ditetapkan dalam SNI 19-6449-2000 termasuk prosedur umum untuk pengolahan dalam rangka mengurangi bahan-bahan terlarut, koloid dan yang tidak mengendap dalam air dengan menggunakan bahan kimia dalam proses koagulasi flokulasi, yang dilanjutkan dengan pengendapan secara gravitasi.

Berdasarkan matriks penelitian yang telah dibahas sebelumnya, dimana pengujian koagulan dengan Jartes ini melibatkan tiga jenis koagulan yaitu nanokitin, kitosan derajat desetilasi $32 \%$ dan kitosan komersil. Ketiga koagulan tersebut divariasikan dengan $\mathrm{pH}$ dan waktu flokulasi (waktu pengadukan lambat), diantaranya $\mathrm{pH} \mathrm{5,} \mathrm{7,} \mathrm{dan} 9$ serta 15 menit, 20 menit dan 25 menit.

Sebelum ketiga koagulan tersebut dimasukkan kedalam 1 liter sampel air yang akan diolah, koagulan nanokitin disiapkan dalam bentuk larutan $0,01 \%$ yaitu 0,01 gram diencerkan dalam $100 \mathrm{ml}$ aquades sedangkan koagulan kitosan 32\% dan kitosan komersil dilarutkan dalam asam asetat $1 \%$ yaitu 1 $\mathrm{ml}$ asam asetat diencerkan dengan $100 \mathrm{ml}$ aquades ditambah kitosan diaduk hingga larut menggunakan magnetic stirer. 
Hasil pengukuran TSS dan COD setelah dilakukan pengolahan koagulasi dan flokulasi serta dengan variasi waktu flokulasi dan nilai $\mathrm{pH}$ dapat dilihat pada Gambar 1-6.

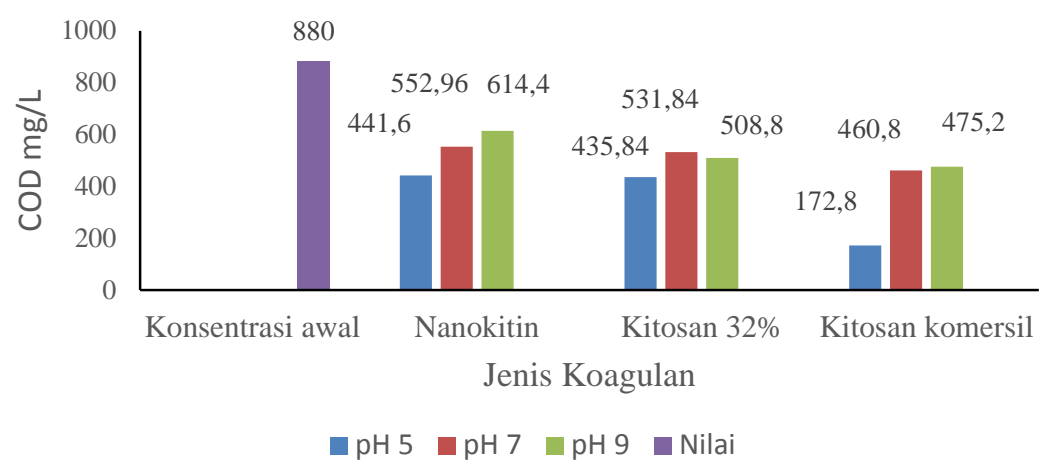

Gambar 1. Hubungan jenis koagulan dengan nilai pH dan waktu flokulasi 15 menit terhadap nilai COD Sumber : Hasil penelitian (2019)

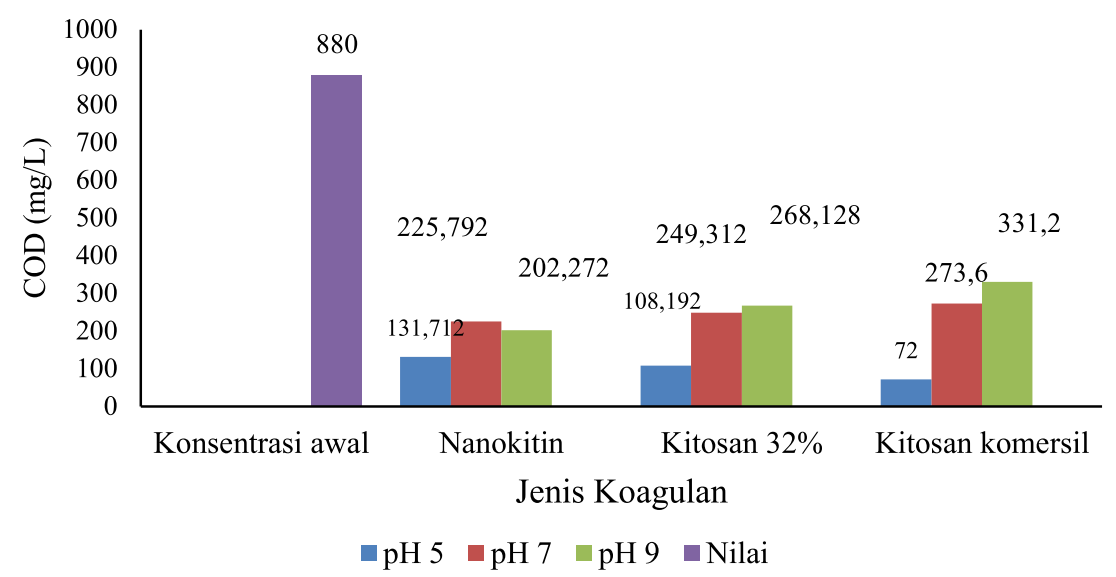

Gambar 2. Hubungan jenis koagulan dengan nilai pH dan waktu flokulasi 20 menit terhadap nilai COD Sumber : Hasil penelitian (2019)

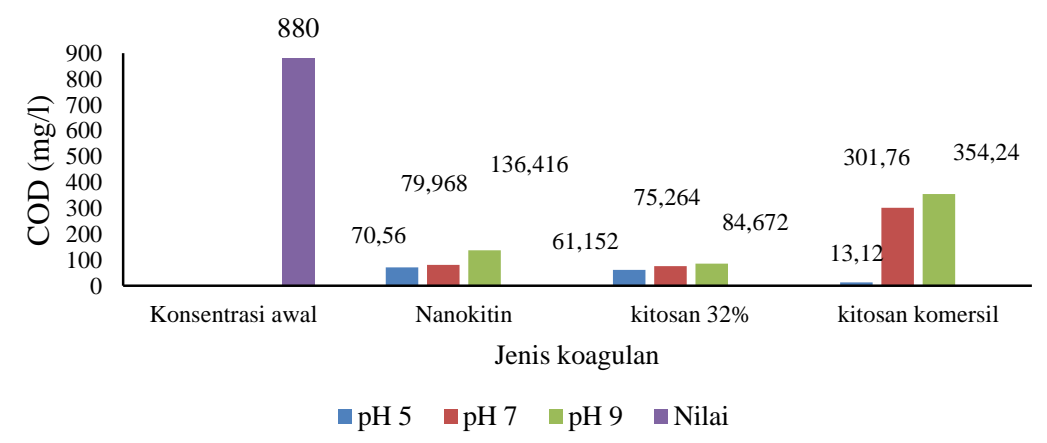

Gambar 3. Hubungan jenis koagulan dengan nilai pH dan waktu flokulasi 25 menit terhadap nilai COD Sumber : Hasil penelitian (2019) 


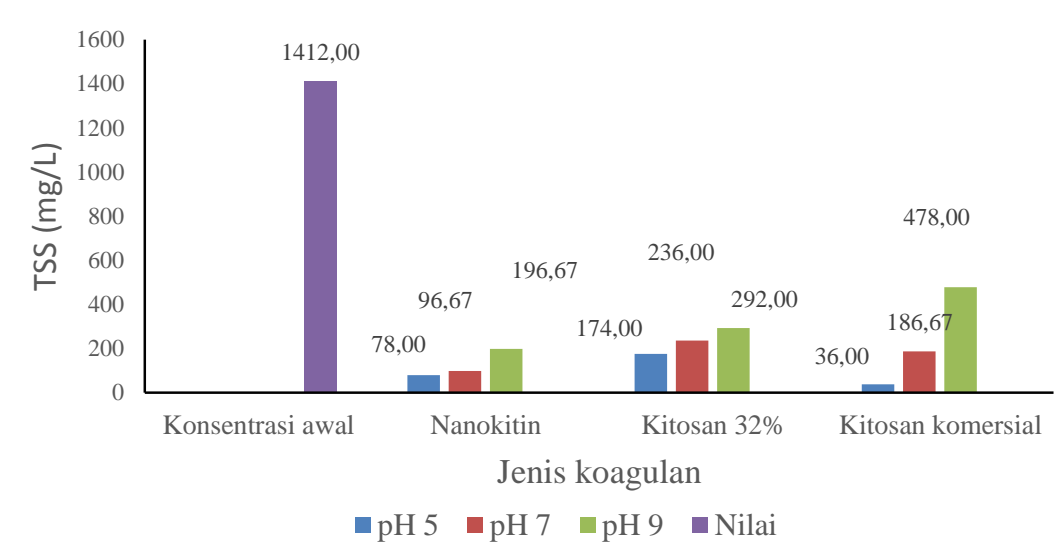

Gambar 4. Hubungan jenis koagulan dengan nilai pH dan waktu flokulasi 15 menit terhadap nilai TSS Sumber : Hasil penelitian (2019)

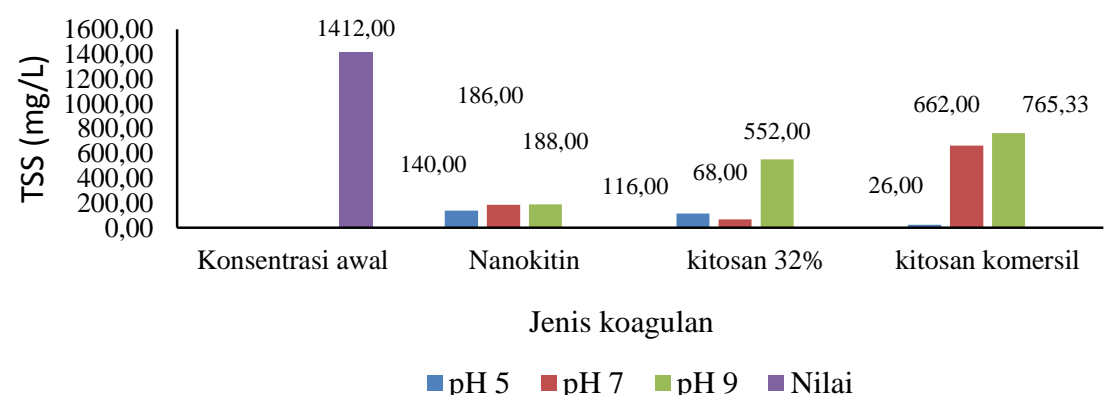

Gambar 5. Hubungan jenis koagulan dengan nilai pH dan waktu flokulasi 20 menit terhadap nilai TSS Sumber : Hasil penelitian (2019)

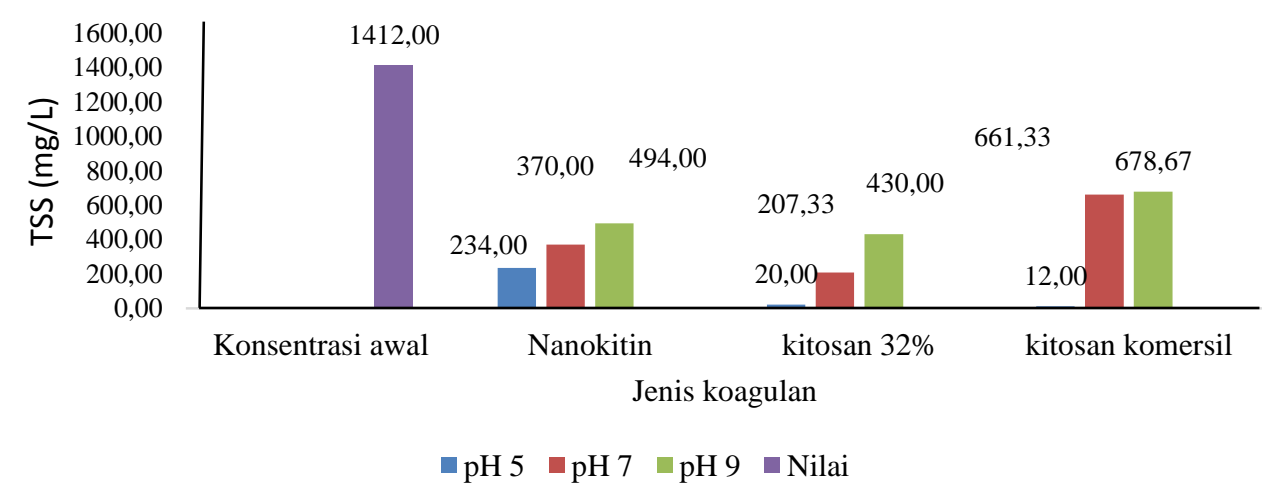

Gambar 6. Hubungan jenis koagulan dengan nilai pH dan waktu flokulasi 25 menit terhadap nilai TSS Sumber : Hasil penelitian (2019)

Nilai COD sampel sebelum dilakukan pengolahan Jartes sebesar $880 \mathrm{mg} / \mathrm{l}$. Hasil tersebut belum memenuhi nilai baku mutu COD sesuai Peraturan Pemerintah No.82 Tahun 2001 kelas I yaitu sebesar 10 $\mathrm{mg} / \mathrm{L}$. Jenis koagulan dan $\mathrm{pH}$ yang berpengaruh terhadap nilai COD pada sampel air Sungai Cikapundung yakni koagulan kitosan komersil pada pH 5 dengan nilai 172,8 mg/L (Gambar 1). Kitosan komersil memiliki nilai derajat deasetilasi yakni sebesar 35,72\% dengan nilai tersebut dapat membuat kitosan sebagai koagulan yang baik hal ini dikarenakan semakin tinggi nilai derajat deasetilasinya maka semakin baik untuk dijadikan koagulan [19]. 
Koagulan yang dapat menurunkan nilai COD pada waktu flokulasi 20 menit dan 25 menit ialah koagulan kitosan komersil sebesar $72 \mathrm{mg} / \mathrm{L}$ dan 13,12 mg/L (Gambar 2 dan 3). Hal ini disebabkan nilai $\mathrm{pH}$ yang mempengaruhi terbentuknya flok terutama pada kitosan yang mempunyai nilai $\mathrm{pH}$ tertentu untuk melarutkan kitosan tersebut, kitosan larut pada kebanyakan larutan asam organik, seperti asam asetat, asam sitrat, asam format, asam piruvat, dan asam maleat pada $\mathrm{pH} \mathrm{4,0} \mathrm{tetapi} \mathrm{tidak} \mathrm{larut} \mathrm{pada} \mathrm{pH}$ lebih besar dari 6,5 [18]. $\mathrm{pH} 5$ yang mendekati asam lebih mudah dalam melarutkan kitosan dibandingkan $\mathrm{pH} 7$ dan pH 9 yang tentu sulit untuk larut. Semakin mudah larut suatu koagulan maka semakin mudah terbentuknya ion polikationik sehingga flok yang dihasilkan lebih banyak dan nilai COD mengalami penurunan. Begitu pula yang terjadi pada waktu flokulasi semakin lama waktu kontak semakin banyak terjadi tumbukkan sehingga flok yang dihasilkan akan lebih banyak, ini dibuktikan pada waktu flokulasi 25 menit yang paling besar menurunkan parameter COD seperti Gambar 4.

Pada data percobaan ini, nilai TSS sebelum dilakukan Jartes didapatkan nilai sebesar $1412 \mathrm{mg} / \mathrm{L}$, Setelah dilakukan proses koagulasi flokulasi jenis koagulan yang mampu menurunkan nilai TSS pada air sampel Sungai Cikapundung yakni koagulan kitosan komersil pada pH 5 sebesar 36 mg/l dengan waktu flokulasi 15 menit (Gambar 5). Nilai ini sudah memenuhi baku mutu Peraturan Pemerintah No.82 Tahun 2001, dimana nilai baku mutu untuk TSS pada kelas I sebesar $50 \mathrm{mg} / \mathrm{l}$. Namun nilai TSS yang paling kecil dihasilkan oleh koagulan kitosan komersil pH 5 waktu flokulasi 25 menit yakni sebesar $12 \mathrm{mg} / \mathrm{L}$. (Gambar 6). Karena kitosan merupakan polisakarida alami non toxic, bersifat biodegradable dan memiliki gugus amina $\left(\mathrm{NH}_{2}\right)$ bebas yang membuat polimer ini bersifat polikationik, sehingga muatan positif dari kitosan akan menetralkan muatan negatif partikel koloid dan akan membentuk flok-flok yang nantinya mudah untuk diendapkan [9]. Sehingga dapat disimpulkan secara keseluruhan maka koagulan yang paling optimal dalam menyisihkan parameter COD maupun TSS ialah kitosan komersil dengan pH 5 waktu detensi 25 menit.

\section{Kesimpulan}

Tahapan proses pembuatan Kitosan dari cangkang Rajungan meliputi proses deproteinasi, demineralisasi, dan deasetilasi. Kemampuan koagulan yang paling optimal dalam proses koagulasi dan flokulasi ialah koagulan kitosan dengan $\mathrm{pH} 5$ dan waktu flokulasi 25 menit yang ditandai dengan pembentukkan flok yang banyak. Hasil pengukuran menunjukkan bahwa koagulan kitosan komersil pada pH 5 waktu flokulasi 25 menit yang dapat menurunkan parameter COD dan TSS dengan dosis koagulan $10 \mathrm{mg} / \mathrm{L}$ pada proses koagulasi dan flokulasi menggunakan alat Jartes dapat menyisihkan COD sebesar 98,51\% dan menyisihkan TSS sebesar 99,15\%. Kitosan komersil dengan nilai derajat deasetilasi 35,72\% dapat menjadi koagulan yang baik. Nilai $\mathrm{pH}$ dalam suasana asam yaitu $\mathrm{pH} 5$ lebih mudah larut dan lebih mudah menghasilkan ion polikationik yang dapat membuat flok yang dihasilkan terendapkan lebih banyak dan lebih cepat. Semakin lama waktu kontak, maka semakin sering terjadinya tumbukan sehingga flok yang dihasilkan lebih banyak dan ini dibuktikan oleh waktu flokulasi yang divariasikan dan dapat berperan optimal dalam menghasilkan flok lebih banyak adalah waktu flokulasi 25 menit.

\section{Daftar Pustaka}

[1] Arga, N.A."Pemanfaatan Cangkang Rajungan sebagai Koagulan Penjernih Air”, Universitas Islam Yogyakarta, 2018.

[2] Anonim.(2009). Standar Nasional Indonesia Metode Pengukuran Chemical Oxygen Demand.

[3] Anonim. (2004). Standar Nasional Indonesia Metode Pengukuran Total Suspended Solid.

[4] Anonim. (2000). Standar Nasional Indonesia Metode Pengujian Koagulasi dan Flokulasi.

[5] Anonim.(2000). Standar Nasional Indonesia Metode Pengambilan Sampel Air Sungai.

[6] Nurmida, R. "Penggunaan Kitosan dan Polyaluminium Chlorida Untuk Menurunkan Kadar Fe dan Zn Dalam Air Gambut" Universitas Sumatera Utara, 2009.

[7] Maharani, D. K. dan Rusmini. Karakterisasi Komposisi Kitosan $\mathrm{SiO}_{2} / \mathrm{ZnO}$ secara Spektrofotometri IR dan Difraksi Sinar-X. Prosiding Seminar Nasional Kimia Unesa. pp. 82-85, 2012.

[8] Nanocomposix.. UV/Vis/IR Spectroscopy Analysis of Nanoparticles.Volume 1.1. pp. 1-6, 2011.

[9] Purwantiningsih, S. Wukirsari, T. Sjahriza, A. dan Wahyono, D. Kitosan Sumber Biomaterial Masa Depan. IPB Press. Bogor, 2009.

[10] Puspawati, N. M. dan Simpen, I. N. Optimasi Deasetilasi Khitin dari Kulit Udang dan Cangkang Kepiting Limbah Restoran Seafood menjadi Khitosan melalui Variasi Konsentrasi NaOH. Jurnal Kimia 4 (1). pp. 79-90, 2010. 
[11] Pitriani, P. Sintesis dan Aplikasi Kitosan dari Cangkang Rajungan (Portunus pelagicus) sebagai Penyerap Ion Besi (Fe) dan Mangan (Mn) untuk Pemurnian Natrium Silikat. Skripsi. UIN Syarif Hidayatullah. Jakarta, Indonesia, 2010.

[12] Rhazi, M. Desbrieres, A. Tolaimate, A. Alagui, A. Vottero, P."Investigation of Different Natural Sources of Chitin: Influence of The Source And Deacetylation Process on The Physicochemical Characteristics Of Chitosan". Polym Int 49. pp. 337-344, 2018.

[13] Rahayu, L. H., dan Purnavita, S. "Optimasi Proses Deproteinasi dan Demineralisasi pada Isolasi Kitin dari Limbah Cangkang Rajungan (Portunus pelagicus)", Prosiding: Teori Aplikasi Teknologi Kelautan, ITS Surabaya. hal. III.8 - III.11, 2004.

[14] Rochima, E. "Karakterisasi Kitin dan Kitosan Asal Limbah Rajungan Cirebon Jawa Barat". Buletin Teknologi Hasil Perikanan X (1). pp. 9-22, 2007.

[15] Rochima, E. "Kajian Pemanfaatan Limbah Rajungan dan Aplikasinya untuk Bahan Minuman Kesehatan Berbasis Kitosan". Jurnal Akuatika V(1) Maret 2015. pp. 71-82, 2014.

[16] Sugita P. “Kitosan: Sumber Biomaterial Masa Depan. Bogor". (ID): IPB Press, 2009.

[17] Srijanto, B. Kajian Pengembangan Teknologi Proses Produksi Kitin dan Kitosan Secara Kimiawi”, Prosiding seminar Nasional Teknik Kimia Indonesia 2003”. Volume I, hal. F01-1 - F01-5, 2013.

[18] Tolaimate, A. Desbrieres, J. Rhazi, M. Alagui, A. "Contribution of The Preparation of Chitin And Chitosan with Controlled Physic-Chemical Properties”. Polymer 44. pp. 7939-7952, 2013.

[19] Yuliastri Indra Rani. "Penggunaan Serbuk Biji Kelor (Moringa Oleifera) Sebagai Koagulan dan Flokulan dalam Perbaikan Kualitas Air Limbah dan Air Tanah". [Tesis]. Universitas Islam Negeri Jakarta, 2010. 